\title{
Introduction
}

\section{Thomas Cohen}

Among the many causes to which António Vieira devoted himself over the course of his long career, two are especially important, both because of the consistency and passion of Vieira's advocacy and because of the consequences of this advocacy in Vieira's life. First, Vieira sought to protect the Brazilian Indians from enslavement by Portuguese settlers, and to enlist the entire Portuguese nation in the conversion of the Indians. Second, Vieira sought to defend the New Christian community (descendants of converted Jews) by representing their interests to the crown and to the Roman Curia, and by curtailing the power of the Portuguese Inquisition. At the heart of this project was Vieira's effort to integrate both the New Christians and the Portuguese Jewish diaspora in the nation's economic and religious life.

Vieira argued that the conversion of the Indians and Jews constituted the point of departure for the universal conversion that had been entrusted by God to the Portuguese crown. Portugal had admitted tens of thousand of Spanish Jews following their expulsion from Spain in 1492. In 1497 these Jews, along with the rest of the Jews of Portugal, were forced by D. Manuel to convert to Christianity. Three years later, with the discovery of Brazil, Portugal initiated an evangelization effort among the Indians that would remain far from finished by the time Vieira made his first missionary journeys in the early 1630s. More than thirty years later, in the course of his defense before the Inquisition, Vieira would argue that, in the conversion of the Indians and Jews,

a large part was played by Divine Providence, which chose [D. Manuel] as the conqueror of so many and such new peoples. And through these peoples God worked with ends that were higher and more hidden than human arguments could contemplate or follow.... During [D. Manuel's] reign the discoveries began, along with the preaching of the gospel throughout the World. And it was this very king who began at the same time to bring to his Kingdom and unite in his Empire the Jewish People (the Jews of Europe) and the gentiles (the peoples of Africa, Asia, and America). ${ }^{1}$

Successive Portuguese monarchs from the Aviz and Bragança dynasties would continue the work of conversion that D. Manuel had begun.

Vieira's practical efforts and prophetic writings in connection with Indians and New Christians constitute the core concerns of the articles in this collection. Taken as a whole, these articles provide a suggestive analysis of the development of Vieira's political activity and millenarian thought from 1652, when he arrived in São Luis do Maranhão to serve as the Superior of the Jesuit missions in the Amazon, to 1697, when he died in Bahia.

As Dauril Alden notes in his perceptive evaluation of Vieira's life and work, portions of Vieira's early career remain shadowy. ${ }^{2}$ Moreover, Vieira's family background has long been the subject of misconceptions. Francis Dutra's article makes an important contribution to our knowledge of Vieira's family and its self-presentation during the latter half of the

\footnotetext{
Luso-Brazilian Review, XXXX I 0024-7413/01/001

(C) 2003 by the Board of Regents of the

University of Wisconsin System
} 
seventeenth century. Given Vieira's writings and practical efforts on behalf of New Christians and Jews, it is not surprising that Vieira was frequently accused-falsely-of having New Christian blood. But the fact that Vieira was an Old Christian did not prevent him from seeking to hide his lineage. ${ }^{3}$ Drawing on extensive archival work, Dutra has discovered that despite the impediment of the family's mulatto blood, Vielra's nephew, Gonçalo Ravasco Cavalcanti e Albuquerque, became a knight in the Order of Christ. Dutra thus makes a valuable correction to the pioneering work of António Baião.

At the age of fifteen, Vieira ran away from home to join the Society of Jesus in Bahia. Soon afterwards, he experienced a revelation during prayer. After he became a public figure, the term estalo de Vieira would pass into the Portuguese language to describe a moment of profound illumination. Vieira preached his first sermon to a brotherhood of black slaves on a sugar mill in the Recôncavo of Bahia in 1633. Embedded in this sermon was a contradiction. Vieira counselled his listeners to accept their earthly lot, as their suffering would be rewarded in heaven. The conflict between Vieira's lifelong defense of Indian freedom and his acceptance-albeit grudging acceptance - of African slavery, is underscored in Maria Beatriz Nizza da Silva's contribution to this volume. Vieira sought to relieve the labor shortage in the Amazon by importing African slaves. He would never resolve the contradiction that was inherent in his views on slavery. ${ }^{4}$

Although Vieira was well known in Brazil as a preacher, he was unknown in Portugal when he was sent to represent Brazil at the court of D. João IV immediately following the Restoration. ${ }^{5}$ Vieira quickly became a favored advisor of D. João IV, serving as both court preacher and roving ambassador. During a diplomatic mission to Amsterdam in 1647-48 Vieira had a series of discussions with the Dutch rabbi Menasseh ben Israel, who in 1650 would publish his messianic treatise, The Hope of Israel.

Vieira's conversations with Menasseh, and his broader exposure to the philosemitic thought that was current in the Europe of his day, transformed his understanding of the church, of the Portuguese nation, and of his own missionary vocation. ${ }^{6}$ Maria Jordán's wideranging article effectively places Vieira's thought within the Christian millenarian tradition and within the political context of post-Restoration Portugal. The church hierarchy, Jordán notes, has viewed millenarian prophecies and movements with suspicion (when it has not actively suppressed them), and has rightly feared the potential for unrest inherent in the interpretation of the literal sense of Scripture that was favored by exegetes such as Vieira.

The "Lusocentric millenarianism" that was to be the defining characteristic of Vieira's prophetic thought began to take shape during Vieira's twelve-year sojourn in Europe. ${ }^{7}$ It was during his mission in the Amazon between 1652 and 1661, however, that Vieira began systematically to develop the link between the conversion of the Indians and the conversion of the Jews. Vieira's ideas about conversion developed against the backdrop of his sustained struggle with the settlers of the Amazon over their illegal enslavement of the Indians. Nizza da Silva and José Eisenberg analyze, respectively, the political context of Vieira's pastoral work, and the nature of his contribution to the debate over Indian slavery.

Nizza da Silva analyzes Vieira's ideas about Indian slavery at two key points in his career: his term as Jesuit Visitor in Maranhão in the 1650s, and his last years in Bahia in the 1690s. The article convincingly documents the transformation of Vieira's thinking about slavery that occurred as a result of his experiences with the Brazilian settlers.

Nizza da Silva calls attention to a little-noted aspect of Vieira's political and pastoral thought, namely, Vieira's insistence that any religious order exercising jurisdiction over the Indians should be prohibited from employing Indian labor on its farms and sugar mills. Despite this insistence, the Portuguese settlers still accused the Jesuits of profiting from Indian labor at the expense of the larger community. Moreover, Vieira's unconcealed contempt for non-Jesuit religious in the colony (and, to a large extent, in Portugal as well) 
fueled animosities that had already made themselves felt within the church in the Amazon. ${ }^{8}$ In general, the other religious orders accommodated the demands of the settlers in a way that the Jesuits were unwilling to do.

Vieira's prophetic discourse was always grounded in political and economic realities. His realism was at no time more apparent than during his mission in the Amazon. In his preaching to the settlers and in the prophetic writings in which he drew on his experience in the Brazilian missions, Vieira always insisted that the missionary enterprise was complementary to-not in conflict with-the settlers' efforts to extract wealth from the colony. As Alcir Pécora aptly observes, Vieira sought to discern the "divine plan of business," and, in doing so, to enlist even his most skeptical audiences in the simultaneous pursuit of the economic and religious goals of the empire. ${ }^{9}$ Writing about the riches of the Portuguese empire in both America and Asia, Vieira affirmed that

the silver, the gold, the rubies, the diamonds, and the emeralds that those lands nourish and hide in their entrails; the unguents, the Brazilwood, the violet, the ebony, the cinnamon, the clove, and the pepper that are born in those lands, were such powerful incentives for man's greed that they made it much easier to bear the dangers and travails of the navigation and conquest of one and the other Indies; for it is certain that if God in His providence had not enriched those lands with those many treasures, no amount of religious zeal would have been sufficient to bring the faith to them. ${ }^{10}$

In contrast with Vieira's prophetic thought, which in recent years has begun to receive the attention from scholars that it deserves, Vieira's political thought has been largely ignored. José Eisenberg's article, by analyzing Vieira's contribution to natural law theory and, more specifically, to the "language of [Jesuit] justifications for slavery," thus constitutes an important contribution to Vieira scholarship. Eisenberg also posits some brief but suggestive conclusions about the comparative history of the Jesuit missionary enterprise in Brazil and Spanish America.

By emphasizing the parallels between the Nóbrega-Caxa debate of 1567 and the debates in which Vieira was engaged between the 1650 s and the 1690 s, Eisenberg reveals the continuities of Jesuit history in Brazil and the development of Vieira's ideas about Indian slavery. Between his arrival in Maranhão in 1652 and his 1694 brief on slavery in São Paulo, Vieira's experiences with the settlers-especially the 1661 expulsion of the Jesuits from Maranhão-increased his animus against them. His willingness to compromise on the subject of the freedom of the Indians was correspondingly diminished.

Vieira was as steadfast in his efforts on behalf of the New Christians and Jews as he was in his defense of the Indians. In this volume, Alcir Pécora, Stuart Schwartz, and I analyze the economic and prophetic underpinnings of these efforts. Vieira paid a high price for his insistence on defending his ideas about New Christians, Jews, and Judaism. Indeed, his defense of these and other ideas for which he was being tried, along with his unwillingness to compromise his own reputation and that of the Society of Jesus, contributed considerably to the prolongation of his Inquisition trial. ${ }^{11}$

The question of Vieira's alleged New Christian ancestry surfaced during the trial but was not systematically pursued by the tribunal. Francis Dutra shows, however, that the general anti-New Christian climate in contemporary Portugal did affect Vieira and his family, especially during the 1670 s. $^{12}$ Between 1669 and 1675 Vieira was in Rome advancing (among other projects) the cause of the Portuguese New Christians at the Curia. His efforts, which did nothing to endear him to D. Pedro II, were instrumental in bringing about the suspension of the Portuguese Inquisition by Pope Clement IX in $1674 .^{13}$ 
Schwartz and Pécora convincingly refute the idea, frequently put forward since the nineteenth century, that Vieira was a progressive or proto-liberal thinker and political actor. ${ }^{14}$ Pécora observes that Vieira can in no way be made to stand as an example of "preEnlightenment consciousness," and that Vieira's economic ideas were "archaic."

Similarly, if Vieira was an advocate for New Christians and Jews, he was not an advocate for the Jewish religion. He planned to write a treatise devoted to the conversion of the Jews, and he stated in his Inquisition defense that "with respect to the Jewish religion, he promises only its total extinction, and the universal conversion of all the Jews." 15

Schwartz and Pécora further refute the commonly held notion that Vieira possessed heterodox religious views, especially concerning New Christians and Jews. Summarizing the multiple influences on Vieira's philosemitism, Schwartz writes that Vieira "united pragmatism and messianism in a singular way that made him an advocate of a more tolerant attitude toward Jews and perhaps a believer in a reconciliation of the two faiths." Pécora analyzes the Inquisition's questioning of Vieira's ideas about such a reconciliation, and concludes that it is "absolutely absurd" to impute to Vieira any heterodox ideas. Vieira argued that eliminating discrimination, integrating New Christians and Jews into Portuguese economic life, and making Jews a central focus of the missionary church, were "the most effective means of extinguishing Judaism, as experience has shown in every realm." 16 Vieira's prophetic writings on New Christians and Jews complemented his attempts in his letters and state papers-especially his 1643 Proposta for D. João IV-to protect the economic interests of New Christians and Jews and to encourage them to invest in Portugal and the empire.

As the articles and book reviews in this volume make clear, António Vieira remains a controversial figure about whom—and from whom—we still have much to learn. Among the most exciting recent developments in scholarship on Vieira is the proliferation of publications of Vieira's own writings, many of which are reviewed in this volume. With the exception of the publication of the Obras Escolhidas, no comparable series of publications of Vieira's writings has ever appeared in so brief a period of time. ${ }^{17}$ Additional publications of Vieira's writings are forthcoming. These include two volumes of Vieira's letters and prophetic writings, to be edited by Alcir Pécora; the completion by Arnaldo do Espírito Santo of his translation of Clavis Prophetarum; and a Latin edition of Clavis Prophetarum that is being prepared by Silvano Peloso.

Preacher, politician, natural law theorist, administrator, diplomat, polemicist, prophetic thinker: Vieira was all of these things, but nothing was more central to his self-definition than his role as a missionary and pastor. ${ }^{18}$ More than forty years ago, Raymond Cantel lamented that it is possible to read most of the scholarly literature on Vieira without realizing that Vieira was a priest. ${ }^{19}$ The contributions to this volume provide a powerful reminder of the fact that we cannot understand Vieira if we do not understand Vieira the priest. It is a much-needed reminder, and one that bears witness to a sustained effort by scholars to bring together the complex strands of Vieira's life and work and to recognize that for Vieira, and for the Jesuit tradition to which he was committed, the ministry of the pastor took precedence over all others. 
NOTES

The articles in this volume were originally presented at a conference, "The Baroque World of Padre António Vieira: Religion, Culture and History in the Luso-Brazilian World," Yale University, November 7-8, 1997, commemorating the three hundredth anniversary of Vieira's death.

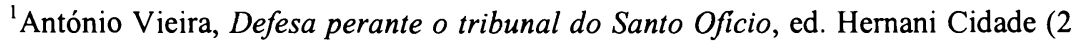
vols., Salvador, Bahia: Publicações da Universidade, 1957), II, 276-77.

2"Some Reflections on António Vieira: Seventeenth-Century Troubleshooter and Troublemaker," below. The standard biography is João Lúcio de Azevedo, História de António Vieira (two vols., Lisbon, Livraria Clássica Editora, 1918-20). For an admiring appreciation of Vieira's achievements, see Charles R. Boxer, A Great Luso-Brazilian Figure: Pe. António Vieira (London: Hispanic and Luso-Brazilian Councils, 1957).

${ }^{3}$ Old Christians throughout early modern Spain and Portugal frequently falsified evidence concerning their lineages for reasons similar to those of Vieira and his family. The family of Theresa de Avila is one famous example among many.

${ }^{4}$ As Luís Palacin has written, "caught between the necessity and the incongruity of slavery and unable either to go against the established order (that is, the rational and moral justification of society itself) or to find a coherent explanation for the existence of slavery, Vieira put off the solution to the life to come." Luís Palacin, Vieira e a visão trágica do barroco: quatro estudos sobre a consciência possivel (São Paulo: Editora Hucitec, 1986).

${ }^{5}$ On Vieira's journey to Portugal, see Alden, "Some Reflections on António Vieira: Seventeenth-Century Troubleshooter and Troublemaker," below.

${ }^{6}$ For a discussion of Vieira's place within Iberian traditions of religious toleration in general and philosemitism in particular, see Stuart Schwartz, "The Contexts of Vieira's Toleration of Jews and New Christians," below.

${ }^{7}$ The reference to "Lusocentric millenarianism" is in José van den Besselaar, "Erudição, espírito crítico e acribia na História do futuro de António Vieira," in Revista da Faculdade de Filosofia, Ciencias e Letras de Marilia (1976) 47.

${ }^{8}$ For a perceptive and detailed analysis of these tensions, see Maxime Haubert, $L$ 'église et la défense des sauvages: le père Antoine Vieira au Brésil (Brussels: Académie Royale des Sciences d'Outre-Mer, 1964).

${ }^{9}$ Pécora, "Uma exegese do capital," below. See also José van den Besselaar, who argues that for Vieira "a dialectical relationship exists between the subjective intentions of men (such as the ambition for wealth) and the objective ends of Providence (the Christianization of the world)." António Vieira, Livro anteprimeiro da história do futuro, ed. José van den Besselaar (two vols., Munster: Aschendorffsche Verlagsbuchhandlung, 1976), Comentário, 12:740.

${ }^{10}$ Livro Anteprimeiro, 12:754. For an analysis of this passage and of Vieira's arguments about the complementarity of trade and evangelization in the imperial enterprise, see Thomas Cohen, The Fire of Tongues: António Vieira and the Missionary Church in Brazil and Portugal (Stanford: Stanford University Press, 1998), 161-62.

11 See António Vieira, Os Autos do Processo de Vieira na Inquisição, ed. Adma Muhana (São Paulo: Editora da Universidade Estadual Paulista; Salvador, Bahia: Fundação Cultural do Estado da Bahia, 1995), editor's introduction, 21.

${ }^{12}$ Dutra notes that D. Pedro "did not want to be seen as 'soft' on the issue of granting knighthoods in the military orders to those who had questions raised about their 'purity of blood," and that this concern likely influenced his decision not to grant a knighthood in the 
Order of Christ to Vieira's younger brother, Bernardo Vieira Ravasco. See Dutra, "The Vieira Family and the Order of Christ," below.

${ }^{13}$ The tribunal was reinstated in 1681 .

${ }^{14}$ For an example of this argument, see Ivan Lins, Aspectos do Padre António Vieira (Rio de Janeiro: Lıvrari São José, 1962).

${ }^{15}$ António Vieira, Os Autos do Processo, op.cit., 182.

${ }^{16}$ António Vieira, Obras Ineditas (three vols., Lisbon: J.M.C. Seabra and V.Q. Antunes, 1856-57) II:74, quoted in Schwartz, "The Contexts of Vieira's Toleration," below.

${ }^{17}$ António Vieira, Obras escolhidas, eds. Hernani Cidade and António Sérgio (Twelve vols., Lisbon: Livraria Sá da Costa Editora, 1951-54).

${ }^{18}$ On the Jesuits' "way of proceeding" and their definition of their ministries, see John

W. O'Malley, The First Jesuits (Cambridge, Mass.: Harvard University Press, 1993).

${ }^{19}$ Raymond Cantel, Prophétisme et messianisme dans l'oeuvre d'António Vieira (Paris: Ediciones Hispano-Americanas, 1960). 